\title{
Correction to: Molecular mechanism study of HGF/c-MET pathway activation and immune regulation for a tumor diagnosis model
}

Zhibo Shen ${ }^{1,2,5 \dagger}$, Wenhua Xue ${ }^{1 \dagger}$, Yuanyuan Zheng ${ }^{1,2,5 \dagger}$, Qishun Geng ${ }^{1,5}$, Le Wang ${ }^{3}$, Zhirui Fan ${ }^{4}$, Wenbin Wang ${ }^{1,5}$, Ying Yue ${ }^{6}$, Yunkai Zhai ${ }^{5}$, Lifeng $\mathrm{Li}^{2,5^{*}}$ and Jie Zhao ${ }^{1,5^{*}}$ (D)

\section{Correction to: Cancer Cell Int (2021) 21:374} https://doi.org/10.1186/s12935-021-02051-2

In this article [1] the wrong figure appeared as Fig. 10c; the correct Fig. 10 should have appeared as shown in this erratum. original author(s) and the source, provide a link to the Creative Commons licence, and indicate if changes were made. The images or other third party material in this article are included in the article's Creative Commons licence, unless indicated otherwise in a credit line to the material. If material is not included in the article's Creative Commons licence and your intended use is not permitted by statutory regulation or exceeds the permitted use, you will need to obtain permission directly from the copyright holder. To view a copy of this licence, visit http://creativecommons.org/licenses/by/4.0/. The Creative Commons Public Domain Dedication waiver (http://creativecommons.org/publicdomain/zero/1.0/) applies to the data made available in this article, unless otherwise stated in a credit line to the data. 


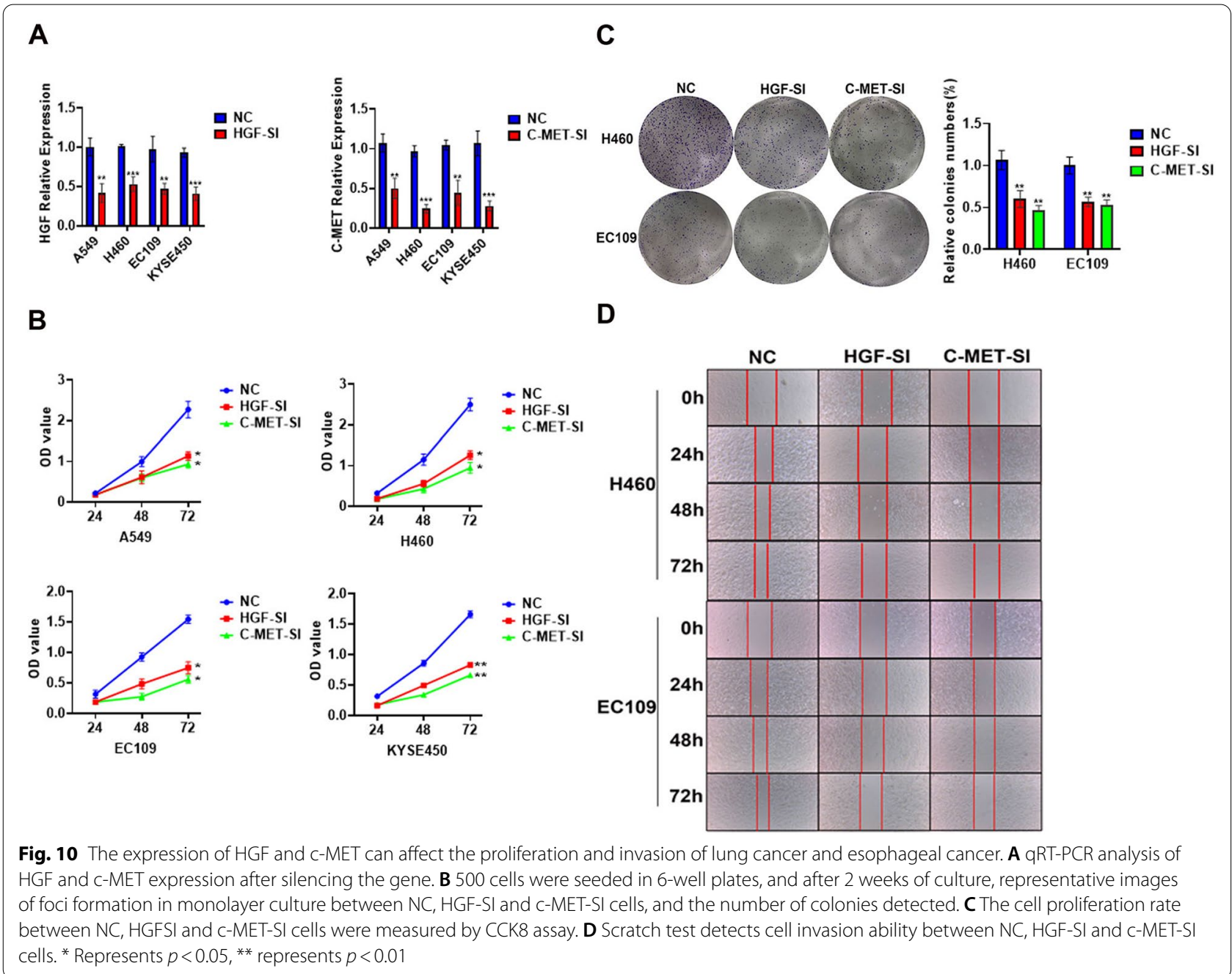

\section{Author details}

'Department of Pharmacy, The First Affiliated Hospital of Zhengzhou University, Zhengzhou 450052, Henan, People's Republic of China. ${ }^{2}$ Cancer Center, The First Affiliated Hospital of Zhengzhou University, Zhengzhou 450052, Henan, People's Republic of China. ${ }^{3}$ Department of Otorhinolaryngology, The First Affiliated Hospital of Zhengzhou University, Zhengzhou 450052, Henan, People's Republic of China. ${ }^{4}$ Department of Traditional Chinese Medicine, The First Affiliated Hospital of Zhengzhou University, Zhengzhou 450052, Henan, People's Republic of China. Internet Medical and System Applications of National Engineering Laboratory, Zhengzhou, China. ${ }^{6}$ Department of Clinical Laboratory, The No.7. People's Hospital of Zhengzhou, Zhengzhou 450016, Henan, China.

Accepted: 24 November 2021

Published online: 14 December 2021

\section{Reference}

1. Shen Z, Xue W, Zheng Y, Geng Q, Wang L, Fan Z, Wang W, Yue Y, Zhai Y, Li L, Zhao J. Molecular mechanism study of HGF/C-MET pathway activation and immune regulation for a tumor diagnosis model. Cancer Cell Int. 2021;21:374. https://doi.org/10.1186/s12935-021-02051-2.

\section{Publisher's Note}

Springer Nature remains neutral with regard to jurisdictional claims in published maps and institutional affiliations. 